\title{
Effect of Integrated Nutrient Management on Soil Biological Properties in Kharif Rice
}

\author{
M. Mallikarjun" and S.K. Maity \\ Department of Agronomy, Institute of Agriculture, Visva-Bharati University, \\ Sriniketan - 731 236, West Bengal, India \\ *Corresponding author
}

\begin{tabular}{|c|}
\hline Keywords \\
\hline $\begin{array}{l}\text { Organic manures, } \\
\text { Inorganic, INM, } \\
\text { Microorganisms }\end{array}$ \\
\hline Article Info \\
\hline $\begin{array}{l}\text { Accepted: } \\
12 \text { October } 2018 \\
\text { Available Online: } \\
10 \text { November } 2018\end{array}$ \\
\hline
\end{tabular}

\section{Introduction}

Sustaining rice production has become a great challenge, particularly in areas where rice productivity declines in spite of following recommended nutrient management practices. Nutrient management by integrating organic sources of nutrients along with inorganic fertilizers may play an important role in improving and sustaining rice productivity
A field experiment was conducted during kharif season of 2015 and 2016 to study the effect of integrated nutrient management (INM) practices on soil biological properties in rice. The experiment was laid out in randomized block design with eight treatments including six INM practices, one chemical practice and one control (i.e. no N) with three replications. The results revealed that biological properties of soil were significantly enhanced by the application of combined use of organic and inorganic fertilizers after harvest of crop during both the years of experimentation. The population of bacteria, fungi and actinomycetes decreased in higher proportion in control. Application of $100 \%$ RDN through chemical fertilizers alone showed a relatively less increase in population of microbes. However, application of organics in the form of farm yard manure (FYM), mustard oil cake (MOC), Green manuring (GM), Brown manuring (BM) and Azolla helped to increase bacteria, actinomycetes, fungi and enzymatic activity in soil over $100 \%$ RDN through chemical fertilizers during both the years of experimentation. The results revealed that treatment $\mathrm{T}_{8}(50 \% \mathrm{~N}$ as chemical fertilizer with $25 \% \mathrm{FYM}$ along with Azolla dual cropping), recorded the maximum load of total bacteria, actinomycetes, fungi and enhanced the activity of urease and dehydrogenase along with soil microbial biomass carbon. Hence replacement of either $25 \% \mathrm{RDN}$ or $50 \%$ RDN of chemical fertilizers through organics is desirable to improve soil health by increasing microbial load and enzymatic activity in the lateritic belt of west Bengal. 
crop production and integrated use of organic and mineral fertilizers has been found to be more effective in maintaining higher productivity and stability through correction of deficiencies of secondary and micronutrients in the course of mineralization on one hand and favorable physical and soil ecological conditions on the other (Mallikarjun and Maity, 2017). Intensive cultivation, growing of exhaustive crops, use of imbalanced and inadequate fertilizers, restricted use of organic manures has made the soils not only deficient in nutrients but also deteriorate soil health resulting decline in crop response to recommended dose of NPK fertilizers. To supply recommended dose of nutrients, large quantities of organic material is needed and also slow release of plant nutrients upon decomposition from organic material deprive crop growth (Goutami et al., 2018). Microorganisms play a definitive and very crucial role in soil fertility. They also play an important role in the decomposition of organic matter and also in decomposition of toxic waste and other pollutants. This living phase is greatly stimulated by organic manure addition which acts as carbon and energy source for proliferating micro-organisms and they may in turn alter the accompanying enzyme status accordingly. Interest in soil enzyme activity has increased recently since their activities are believed to reflect the potential capacity of soil to perform nutrient transformations. Since, soil microbial and enzyme systems are associated with organic manure management, incorporation of organic manures into soil not only plays an important role in soil chemical and biological activity, but also affects the rate at which nutrients become available to crop plants as well as other forms of life. To achieve the sustained soil fertility and crop productivity the role of organic manures are very important. These organic manures, in addition to nutrient supply they have microbial load and growth promoting substances which helps in improving the plant growth, metabolic activity and resistance to pest and diseases. The information on effect of integrated nutrient management practices on biological properties of soil is new under the lateritic belt of West Bengal. Keeping these aspects in view, the present research work was undertaken to study the effect of integrated nutrient management practices on biological properties of soil.

\section{Materials and Methods}

The field experiment was conducted during kharif seasons of 2015 and 2016 at Agricultural Farm of Palli Siksha Bhavana (Institute of Agriculture), Visva-Bharati,

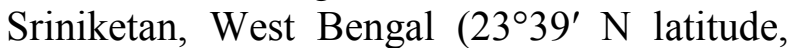
$87^{\circ} 42^{\prime} \mathrm{E}$ longitude and an altitude of $58.9 \mathrm{~m}$ above sea level), to study the effect of Integrated Nutrient Management on soil microorganisms and enzymatic activity in rice. The experimental soil is fragile, lateritic and sandy-loam in texture $(60 \%$ sand, $23.2 \%$ silt and $16.3 \%$ clay). The experiment was laid out in the randomized block design with three replications each consisting of eight treatments applied to kharif rice. These were $\mathrm{T}_{1}=$ Control (No nitrogen), $\mathrm{T}_{2}=100 \%$ recommended dose of nitrogen (RDN) through chemical fertilizers, $\mathrm{T}_{3}=75 \% \mathrm{RDN}$ (chemical fertilizer) $+25 \%$ RDN as farm yard manure (FYM), $\mathrm{T}_{4}=75 \%$ RDN (chemical fertilizer) $+25 \%$ RDN as mustard oil cake (MOC), $\mathrm{T}_{5}=75 \% \mathrm{RDN}$ (chemical fertilizer) + dhaincha green manuring, $\mathrm{T}_{6}=75 \% \mathrm{RDN}$ (chemical fertilizer) + dhaincha brown manuring, $\mathrm{T}_{7}=75 \% \mathrm{RDN}$ (chemical fertilizer) + Azolla dual cropping, $\mathrm{T}_{8}=50 \% \mathrm{RDN}$ (chemical fertilizer) $+25 \%$ RDN as FYM + Azolla dual cropping. The recommended dose of fertilizer for kharif rice was $80 \mathrm{~kg} \mathrm{~N}, 40 \mathrm{~kg}$ $\mathrm{P}_{2} \mathrm{O}_{5}$ and $40 \mathrm{~kg} \mathrm{~K}_{2} \mathrm{O} \mathrm{ha}^{-1}$ (RDF). The rice variety used under study was MTU 1010. The average nutrient composition of different organic sources applied and their NPK content are presented in Table 1. 
Soil samples were collected after harvest of rice during both the years from a depth of 0-15 $\mathrm{cm}$ with the help of soil auger from 10 different points within the individual replicated plots of respective treatments. These samples were preserved, processed and analyzed following the standard procedures as indicated in Table 2. The data were statistically analyzed by the analysis of variance method as suggested Gomez and Gomez (1984). The significance of different sources of variations was tested by error mean square of Fisher and Snedecor's ' $F$ ' test at probability level of 0.05 . Fisher and Yate's tables were consulted for the determination of least significant difference (LSD) at 5\% level of significance. The value standard error of mean $(\mathrm{SEm}+)$ and the LSD was used to compare the difference between the treatment means.

\section{Results and Discussion}

\section{Bacteria}

The bacterial load in the soil was significantly influenced by different $\mathrm{N}$ management practices after harvest of the crop in either of the two years of experimentation (Table 3). The nitrogen receiving treatments $\left(T_{2}\right.$ to $\left.T_{8}\right)$ recorded significantly higher bacterial count than control during both the years of experimentation. During both the years of experimentation the highest bacterial count (39.4 X $10^{5} \mathrm{CFU} \mathrm{g}^{-1}$ and $40.5 \times 10^{5} \mathrm{CFU} \mathrm{g}^{-1}$ in the year 2015 and 2016, respectively) was observed with treatment $\mathrm{T}_{8}(50 \% \mathrm{~N}$ as chemical fertilizer with 25\% FYM along with Azolla dual cropping) being statistically at par with treatment $\mathrm{T}_{7}(75 \% \quad \mathrm{~N}$ as chemical fertilizer along with Azolla dual cropping). The application of organics along with chemical fertilizers registered a significant increase in bacterial population over control. These results are in confirmative with those of Krishnakumar et al., (2005) and Kumari et al., (2017). They have reported an increase in bacterial count with application of different organic $\mathrm{N}$ sources compared to control (Krishnakumar et al., 2005) with justification to the findings of present experimentation.

\section{Fungi}

All the treatments receiving nitrogen application $\left(T_{2}\right.$ to $\left.T_{8}\right)$ recorded at par fungal population with each other being significantly higher than control (i.e. no N) during both the years of experimentation. Among the treatments receiving nitrogen $\left(T_{2}\right.$ to $\left.T_{8}\right)$ the highest fungal population $\left(14.06 \times 10^{3} \mathrm{CFU}\right.$ $\mathrm{g}^{-1}$ and $15.08 \times 10^{3} \mathrm{CFU} \mathrm{g}^{-1}$ in the year 2015 and 2016, respectively) was observed with treatment $\mathrm{T}_{8}(50 \% \mathrm{~N}$ as chemical fertilizer with 25\% FYM along with Azolla dual cropping). Kumari et al., (2017) and Kuttimani et al., (2017) revealed that the fungal population had a positive correlation with addition of organic sources of nutrients in the treatments.

\section{Actinomycetes}

All the treatments involving nitrogen application $\left(\mathrm{T}_{2}\right.$ to $\left.\mathrm{T}_{8}\right)$ recorded at par actinomycetes population with each other being significantly higher than control (i.e. no $\mathrm{N})$ during both the years of experimentation. Among the treatments receiving nitrogen $\left(T_{2}\right.$ to $\mathrm{T}_{8}$ ) the highest actinomycetes population (30.2 X 10 ${ }^{2} \mathrm{CFU} \mathrm{g}^{-1}$ and $32.8 \times 10^{2} \mathrm{CFU} \mathrm{g}^{-1}$ in the year 2015 and 2016, respectively) was observed with treatment $\mathrm{T}_{8} \quad(50 \% \quad \mathrm{~N}$ as chemical fertilizer with 25\% FYM along with Azolla dual cropping). The lowest actinomycetes population $\left(25.4 \times 10^{2} \mathrm{CFU} \mathrm{g}^{-1}\right.$

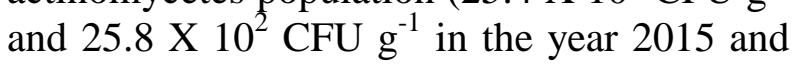
2016, respectively) was observed with treatment $\mathrm{T}_{2}(100 \% \mathrm{~N}$ as chemical fertilizer) among all the treatments involving nitrogen application $\left(\mathrm{T}_{2}\right.$ to $\left.\mathrm{T}_{8}\right)$. In the soil profile bacterial population are predominant followed by actinomycetes and fungi. 


\section{Urease activity}

The data (Table 4) revealed that, urease activity increased over the years except in treatment $\mathrm{T}_{1}$ (i.e. control). All the treatments receiving nitrogen application either in the form of chemical alone or combination of chemical and organic recorded significantly higher urease activity than $\mathrm{T}_{1}$ (i.e. control) after harvest of rice during both the years. During the first year of experimentation (2016), the highest urease activity was observed with treatment $\mathrm{T}_{8}(50 \% \mathrm{~N}$ as chemical fertilizer with $25 \%$ FYM along with Azolla dual cropping) and it was significantly superior over all other treatments. During the second year of experimentation (2017), though the highest urease activity was observed with treatment $\mathrm{T}_{8}(50 \% \mathrm{~N}$ as chemical fertilizer with 25\% FYM along with Azolla dual cropping) but it remained at par with treatments $\mathrm{T}_{3}(75 \% \mathrm{~N}$ as chemical fertilizer with $25 \% \mathrm{FYM})$ and $\mathrm{T}_{6}(75 \% \mathrm{~N}$ as chemical fertilizer with dhaincha brown manuring). The higher urease activity under INM practices in rice might be due to presence of extra cellular urease adsorbed on finer components of organic matter or may be because of higher organic matter in soil that stimulates the ureolytic micro-organisms by serving as source of carbon, energy and other nutrients essential for microbial growth and multiplication (Reddy, 2002). The treatment $\mathrm{T}_{2}$ i.e. $100 \% \mathrm{~N}$ as chemical fertilizer recorded lower urease activity than the INM treatments which might have been attributed due to lack of sufficient substrate i.e. organic carbon which acts as an energy source and food for proliferating the microbial population (Nagendra, 2015).

Table.1 N, P and K content (\%) of organic materials used

\begin{tabular}{|c|c|c|c|c|c|c|}
\hline \multirow[t]{3}{*}{ Materials used } & \multicolumn{6}{|c|}{ Content (\%) } \\
\hline & \multicolumn{2}{|c|}{$\mathbf{N}$} & \multicolumn{2}{|c|}{$\mathbf{P}$} & \multicolumn{2}{|c|}{$\mathbf{K}$} \\
\hline & 2015 & 2016 & 2015 & 2016 & 2015 & 2016 \\
\hline FYM* & 0.58 & 0.72 & 0.12 & 0.15 & 0.58 & 0.66 \\
\hline Mustard oil cake* & 5.22 & 5.16 & 0.86 & 0.80 & 1.10 & 1.05 \\
\hline Dhaincha green manuring*** & 3.21 & 3.43 & 0.23 & 0.26 & 0.99 & 0.95 \\
\hline Dhaincha brown manuring*** & 3.32 & 3.50 & 0.28 & 0.27 & 1.01 & 0.95 \\
\hline Azolla $\left(\mathbf{T}_{7}\right)^{* * * *}$ & 4.47 & 4.24 & 0.51 & 0.53 & 2.43 & 2.58 \\
\hline Azolla $\left(\mathrm{T}_{8}\right)^{* * *}$ & 4.64 & 4.78 & 0.49 & 0.61 & 2.37 & 2.53 \\
\hline
\end{tabular}

Table.2 Standard procedures flowed for determination of biological properties of soil

\begin{tabular}{|c|c|c|}
\hline S. No & Particulars & Standard method followed/ Media used \\
\hline 1 & Bacteria & Thorntons media for Total bacterial count (Thornton 1930) \\
\hline 2 & Fungi & Rose streptomycin Bengal media for fungi (Rao 1988) \\
\hline 3 & Actinomycetes & Caseinate Agar Media for Actinomycetes (Rao 1988) \\
\hline 4 & Urease & $\begin{array}{c}\text { Release of NH4-N from the hydrolysis of urea as described } \\
\text { by Tabatabai and Bremner (1972) }\end{array}$ \\
\hline 5 & Dehydrogenase & $\begin{array}{l}\text { production of tri-phenyl formazan (TPF) from triphenyl } \\
\text { tetrazolium (Casida et al., 1964) }\end{array}$ \\
\hline 6 & Soil microbial biomass carbon & Fumigation extraction method by Beck et al., (1997) \\
\hline
\end{tabular}


Table.3 Effect of integrated nutrient management practices on soil bacteria, soil fungi and soil actinomycetes

\begin{tabular}{|c|c|c|c|c|c|c|}
\hline \multirow[t]{2}{*}{ Treatments } & \multicolumn{2}{|c|}{$\begin{array}{c}\text { soil bacteria } \\
\left(\mathrm{CFU} \times 105 \mathrm{~g}^{-1}\right)\end{array}$} & \multicolumn{2}{|c|}{$\begin{array}{c}\text { soil fungi } \\
\left(\mathrm{CFU} \times 103 \mathrm{~g}^{-1}\right)\end{array}$} & \multicolumn{2}{|c|}{$\begin{array}{l}\text { soil actinomycetes } \\
(\text { CFU } \times 102 \mathrm{~g}-1)\end{array}$} \\
\hline & 2016 & 2017 & 2016 & 2017 & 2016 & 2017 \\
\hline T1:Control & 20.4 & 20.2 & 4.91 & 4.83 & 17.1 & 16.7 \\
\hline T2:100\% RDN & 26.0 & 26.9 & 12.22 & 13.25 & 25.4 & 25.8 \\
\hline T3:75\% RDN+25\%FYM & 32.3 & 33.1 & 13.13 & 13.91 & 26.6 & 27.5 \\
\hline T4:75\% RDN+25\%MOC & 29.5 & 29.9 & 12.45 & 12.88 & 25.5 & 26.1 \\
\hline T5:75\% RDN+Dhaincha GM & 32.6 & 35.3 & 13.67 & 14.03 & 28.4 & 29.3 \\
\hline T6:75\% RDN+ Dhaincha BM & 32.1 & 33.6 & 13.19 & 14.02 & 26.7 & 28.4 \\
\hline T7:75\% RDN+Azolla & 34.7 & 35.6 & 13.66 & 14.00 & 28.3 & 28.4 \\
\hline T8:50\% RDN+25\%FYM+Azolla & 39.4 & 40.5 & 14.06 & 15.08 & 30.2 & 32.8 \\
\hline $\operatorname{SEm}( \pm)$ & 2.2 & 1.6 & 1.55 & 1.34 & 1.8 & 2.4 \\
\hline $\mathbf{L S D}_{0.05}$ & 6.6 & 4.9 & 4.69 & 4.06 & 5.3 & 7.3 \\
\hline
\end{tabular}

$\mathrm{T}_{1}$ : Control, $\mathrm{T}_{2}: 100 \% \mathrm{RDN}, \mathrm{T}_{3}: 75 \% \mathrm{RDN}+25 \% \mathrm{FYM}, \mathrm{T}_{4}: 75 \% \mathrm{RDN}+25 \% \mathrm{MOC}, \mathrm{T}_{5}: 75 \% \mathrm{RDN}+$ dhaincha $\mathrm{GM}, \mathrm{T}_{6}: 75 \% \mathrm{RDN}+$ dhaincha $\mathrm{BM}, \mathrm{T}_{7}: 75 \% \mathrm{RDN}+$ Azolla, $\mathrm{T}_{8}: 50 \% \mathrm{RDN}+25 \% \mathrm{FYM}+$ Azolla, RDN: Recommended dose of nitrogen $\left(80 \mathrm{KG} \mathrm{N} \mathrm{Na}^{-1}\right)$.

Table.4 Effect of integrated nutrient management practices on soil urease activity, soil dehydrogenase activity and Soil microbial biomass carbon

\begin{tabular}{|c|c|c|c|c|c|c|}
\hline \multirow[t]{2}{*}{ Treatments } & \multicolumn{2}{|c|}{$\begin{array}{c}\text { soil urease activity } \\
\left(\mu \mathrm{g} \mathrm{NH}_{4}^{+}-\mathrm{Ng}^{-1} \text { soil } \mathbf{h}^{-1}\right)\end{array}$} & \multicolumn{2}{|c|}{$\begin{array}{l}\text { soil dehydrogenase activity } \\
\text { ( } \mu \mathrm{g} \text { of TPF g-1 soil Day-1) }\end{array}$} & \multicolumn{2}{|c|}{$\begin{array}{l}\text { Soil microbial biomass carbon } \\
\text { (mg kg }\end{array}$} \\
\hline & 2016 & 2017 & 2016 & 2017 & 2016 & 2017 \\
\hline T1:Control & 24.76 & 20.57 & 219.6 & 214.1 & 178.0 & 175.4 \\
\hline T2:100\% RDN & 29.34 & 30.98 & 327.2 & 323.7 & 319.8 & 315.9 \\
\hline T3:75\% RDN+25\%FYM & 38.15 & 40.10 & 352.5 & 362.2 & 333.7 & 340.0 \\
\hline T4:75\% RDN+25\%MOC & 32.71 & 32.90 & 342.5 & 361.3 & 327.0 & 330.3 \\
\hline T5:75\% RDN+Dhaincha GM & 35.50 & 37.37 & 371.9 & 384.0 & 328.8 & 334.4 \\
\hline T6:75\% RDN+ Dhaincha BM & 37.92 & 38.70 & 371.1 & 387.4 & 352.4 & 359.9 \\
\hline T7:75\% RDN+Azolla & 36.01 & 36.61 & 359.6 & 378.0 & 329.4 & 337.8 \\
\hline T8:50\% RDN+25\% FYM+Azolla & 42.26 & 42.98 & 411.2 & 414.5 & 358.8 & 366.2 \\
\hline $\operatorname{SEm}( \pm)$ & 1.19 & 1.37 & 12.7 & 18.8 & 24.37 & 22.81 \\
\hline $\mathbf{L S D}_{0.05}$ & 3.61 & 4.14 & 38.5 & 57.2 & 73.91 & 69.19 \\
\hline
\end{tabular}

$\mathrm{T}_{1}:$ Control, $\mathrm{T}_{2}: 100 \% \mathrm{RDN}, \mathrm{T}_{3}: 75 \% \mathrm{RDN}+25 \% \mathrm{FYM}, \mathrm{T}_{4}: 75 \% \mathrm{RDN}+25 \% \mathrm{MOC}, \mathrm{T}_{5}: 75 \% \mathrm{RDN}+$ dhaincha $\mathrm{GM}, \mathrm{T}_{6}: 75 \% \mathrm{RDN}+$ dhaincha $\mathrm{BM}, \mathrm{T}_{7}: 75 \% \mathrm{RDN}+$ Azolla, $\mathrm{T}_{8}: 50 \% \mathrm{RDN}+25 \% \mathrm{FYM}+$ Azolla, RDN: Recommended dose of nitrogen $\left(80 \mathrm{KG} \mathrm{N} \mathrm{ha}^{-1}\right)$. 


\section{Dehydrgenase}

Dehydrogenase is involved in the respiratory chain of micro organisms and their activities often serve as an index of microbial biomass. The dehydrogenase activity increased over the years except in treatment $\mathrm{T}_{1}$ (i.e. control) and $\mathrm{T}_{2}(100 \% \mathrm{~N}$ as chemical fertilizer) where these two treatments showed decrease in urease activity over first year. All the treatments receiving nitrogen application either in the form of chemical alone or combination of chemical and organic sources recorded significantly higher dehydrogenase activity than $\mathrm{T}_{1}$ (i.e. control). The highest dehydrogenase activity during both the years was observed in treatment $\mathrm{T}_{8}(50 \% \mathrm{~N}$ as chemical fertilizer with $25 \%$ FYM along with Azolla dual cropping), where it recorded significantly higher dehydrogenase activity over all other treatments in first year, whereas the INM treatments with $25 \%$ replacement of chemical nitrogen by organic sources (i.e. $\mathrm{T}_{3}$ $\mathrm{T}_{7}$ ) remained at par withhighest value for dehydrogenase activity during the second year of experimentation. The increase in dehydroenase activity in INM treatments might be due to formation of humic acids that enhanced the activity of micro-organisms in soil that ultimately resulted in increase of dehydrogenase activity in soil (Bajpai et al., 2006). The application of organic manures along with inorganic fertilizers increased the dehydrogenase activity (Liu et al., 2010).

\section{Soil microbial biomass carbon}

Soil microbial biomass carbon in soil samples showed a significant effect among different treatments (Table 4). The treatment $\mathrm{T}_{8}(50 \%$ $\mathrm{N}$ as chemical fertilizer with $25 \%$ FYM along with Azolla dual cropping) had recorded the highest SMBC and the control treatment recorded the lowest SMBC contents during both the years of experimentation. All the treatments involving nitrogen application $\left(\mathrm{T}_{2}-\right.$
$\mathrm{T}_{8}$ ) recorded significantly higher SMBC than $\mathrm{T}_{1}$ (i.e. Control). All the INM treatments $\left(\mathrm{T}_{3^{-}}\right.$ $\mathrm{T}_{8}$ ) recorded slightly higher values of SMBC than treatment $\mathrm{T}_{2}(100 \%$ RDN through chemical fertilizers). The increase in SMBC in treatments with added organic sources $\left(\mathrm{T}_{3}\right.$ $\mathrm{T}_{8}$ ) could be attributed to an increase in microbial biomass compared to other treatments due to availability of substrates for growth of microbial population. Similar reports of increased SMBC in treatments where balanced fertilization with organic amended was observed Kumari et al., (2017).

Hence it can be concluded that replacement of a part of recommended dose of nitrogen by addition of organic manures can be an ideal option for sustaining of soil fertility in terms of soil biological properties of lateritic belt of West Bengal.

\section{References}

Bajpai, R.K., Chitale, S., Upadhyay, S.K. and Urkurkar, J.S., 2006. Long-term studies on soil physico-chemical properties and productivity of rice-wheat system as influenced by integrated nutrient management in Inceptisol of Chhattisgarh. Journal of the Indian Society of Soil Science, 54(1), pp.24-29.

Beck, T., Joergensen, R.G., Kandeler, E., Makeschin, F., Nuss, E., Oberholzer, H.R. and Scheu, S., 1997. An interlaboratory comparison of ten different ways of measuring soil microbial biomass C. Soil Biology and Biochemistry, 29(7), pp.1023-1032.

Casida Jr, L.E., Klein, D.A. and Santoro, T., 1964. Soil dehydrogenase activity. Soil science, 98(6), pp.371-376.

Gomez, K.A., Gomez, K.A. and Gomez, A.A., 1984. Statistical procedures for agricultural research. John Wiley \& Sons. 
Goutami, N., Ch. Sujani Rao, A. Sireesha, Ch. Pulla Rao and Vijaya Gopal, A. 2018. Effect of Long-Term Use of Inorganic Fertilizers, Organic Manures and Their Combination on Soil Properties and Enzyme Activity in Rice-Rice Cropping System. Int.J.Curr.Microbiol.App.Sci. 7(09): 469-486.

Kumari, S., Chattopadhyaya, N., Mandal, J. and Singh, M., 2017. Integrated Nutrient Management boost the soil biological properties in rice rhizosphere. Journal of Crop and Weed, 13(1), pp.116-124.

Kuttimani, R., Somasundaram, E. and Velayudham, K., 2017. Effect of Integrated Nutrient Management on Soil Microorganisms under Irrigated Banana. International Journal of Current Microbiology and Applied Science, 6(11), pp.2342-2350.

Liu, E., Yan, C., Mei, X., He, W., Bing, S.H., Ding, L., Liu, Q., Liu, S. and Fan, T., 2010. Long-term effect of chemical fertilizer, straw, and manure on soil chemical and biological properties in northwest China. Geoderma, 158(3-4), pp.173-180.

Mahajan A and Gupta R D. 2009. Integrated nutrient management (INM) in a sustainable rice-wheat cropping system. Springer Science \& Business Media. pp 140.

Mallikarjun, M. and Maity, S.K., 2017. Energetic Evaluation of Integrated Nutrient Management for Nitrogen in Kharif Rice and its Residual Effect on Yellow Sarson. Research Journal of
Agricultural Sciences, 8(6), pp.13621365.

Mandal, A., Patra, A.K., Singh, D., Swarup, A. and Masto, R.E., 2007. Effect of long-term application of manure and fertilizer on biological and biochemical activities in soil during crop development stages. Bioresource technology, 98(18), pp.3585-3592.

Mondal S, Mallikarjun M, Ghosh M, Ghosh D C and Timsina J. 2016. Influence of integrated nutrient management (INM) on nutrient use efficiency, soil fertility and productivity of hybrid rice. Archives of Agronomy and Soil Science 62(11): 1521-1529.

Nagendra, V., 2015. Influence of Rice Production Systems and Nutrient Management Practices on Rice Yield and Soil Properties (Doctoral Dissertation, Professor Jayashankar Telangana State Agricultural University, Rajendranagar, Hyderabad).

Rao, N.S., 1988. Biofertilizers in Agriculture Published by Oxford and IBH Publishing Company private limited, New Delhi.

Reddy, M.S., 2002. Relationship between organic carbon and soil enzymes. $J$. Res. ANGRAU, 30(2), 143-146.

Tabatabai, M.A. and Bremner, J.M., 1972. Assay of urease activity in soils. Soil Biology and Biochemistry, 4(4), 479487.

Thornton, H.G., 1930. The early development of the root nodule of lucerne (Medicago sativa, L.). Annals of Botany, 44(174), pp. 385-392.

\section{How to cite this article:}

Mallikarjun, M. and Maity, S.K. 2018. Effect of Integrated Nutrient Management on Soil Biological Properties in Kharif Rice. Int.J.Curr.Microbiol.App.Sci. 7(11): 1531-1537. doi: https://doi.org/10.20546/ijcmas.2018.711.176 